\title{
REPRESENTATION AND PERCEPTION OF ROMAN IMPERIAL POWER IN GREEK PAPYRUS TEXTS FROM AD $238^{1}$
}

By

\section{JANNEKE DE JONG}

'What's in a title?' At first sight, this question may seem a little awkward. In fact, it is hard to answer a question like this without a context and a certain amount of background information. Therefore, before I get into a more detailed discussion of what the title of this paper suggests, I will give a brief sketch of the framework in which I would like to put this question.

To begin with, let us define time, place and subject of investigation. In this paper that will be imperial titulature in Greek papyrus texts from Egypt, from $\mathrm{AD} 238$. This year is highly interesting for Roman imperial history, with an empire-wide revolt and no less than seven different emperors who were recognized by the senate and people of Rome. That they were officially recognized in Egypt too, is proved by a number of papyrus texts from this province. In what follows, some of those texts will be considered in light of their meaning for Roman authority. Based on those texts a hypothesis will be put forward, speculative though it may be, regarding representation and perception of Roman imperial power in Egypt.

Military difficulties started to occur from the second half of the second century onwards. ${ }^{2}$ During the reign of Marcus Aurelius there were problems at the frontiers; ${ }^{3}$ in addition, the succession by his son Commodus marked the end of the 'golden age' of adoptive emperors. ${ }^{4}$ When Commodus was killed, a new emperor was proclaimed, P. Helvius Pertinax, who was killed soon after his imperial proclamation. As a result of this, a civil war

\footnotetext{
${ }^{1}$ This paper was presented as a poster at the 3 rd workshop of the international network 'Impact of Empire', 20-23 March 2002 in Rome. It serves as an illustrating example for a wider topic, i.e. imperial representation in the late $2^{\text {nd }}$ and $3^{\text {rd }}$ century $\mathrm{AD}$, which I will deal with in my $\mathrm{PhD}$ study. The major part of the research was carried out during a stay in Heidelberg. An early and preliminary draft of this paper was read by M. Peachin and T. Kruse, who both have made useful suggestions, and to whom I express my thanks. I owe further thanks to D. Hagedorn, who kindly showed me two unedited Heidelberg papyrus texts from $\mathrm{AD} 238$, to which reference is made in the appendix (nos. 11 and 12).

${ }^{2}$ L. de Blois, 'Emperor and Empire in the Works of Greek Authors', in W. Haase and H. Temporini (Hrsgg.) Aufstieg und Niedergang der Römischen Welt II 34, 4 (1998), 3395-3396, esp. note 10 and 11 for an extensive bibliography.

${ }^{3}$ A. Birley, Marcus Aurelius. A Biography (London 1987), 121-126; 140-151; 159-183.

${ }^{4}$ For the succession of Marcus Aurelius by Commodus and its place in dynastic policy, see O.J. Hekster, Commodus. An Emperor at the Crossroads (Amsterdam 2002), 15-39. For the historical background and the political struggle following the murder of Commodus see: A. Birley, Septimius Severus. The African Emperor, (London 1988), 89-128.
} 
was fought between the most important military leaders, with the emperorship at stake. The winner of this civil war, Septimius Severus, founded a new dynasty. It now became visible that the character of emperorship had changed. More openly than ever before, the emperor's position was based on military support. Still, Septimius Severus managed to create an appearance of dynastic continuity by linking himself to the family of Marcus Aurelius. ${ }^{5}$ That he succeeded in doing so is proved by the fact that his dynasty lasted for more than four decades. But, by then, the problems had increased and the last ruling Severan, Severus Alexander, no longer enjoyed trust and loyalty from his soldiers. When he was murdered by his own troops, the dynastic continuity of emperors of the first two centuries had come to an end. The next half-century faced many short rules of so-called soldier emperors. The first one of low background was Maximinus Thrax. ${ }^{6}$ He had not even reigned for three years when a revolt broke out in Thysdrus (Africa) that spread all over the empire. Between the beginning of this revolt and the accession of the third Gordian, in the second half of 238 , there had been four other claimants to the throne, but none of them survived the battle for the purple. However short their reigns may have been, we know they were officially recognized as emperors in various provinces, including Egypt. ${ }^{7}$ In this paper, the papyrological evidence from Egypt will be taken into account. Only few papyri from $\mathrm{AD} 238$ are preserved: a search in the Heidelberger Gesamtverzeichnis results in 11 papyri (and two inedited Heidelberg papyri) that can surely be dated to $\mathrm{AD} 238$. Still, they represent the reigns of all seven emperors that this year saw. Examination of imperial elements will reveal both conspicuous similarities and differences in the rendering of the titles of the different emperors. The question to be considered below is whether those similarities and differences allow us to make presumptions on presentation and perception of the imperial power.

Before I turn to the discussion of the relevant papyrus texts, some remarks on papyrus texts in general need to be made. One must realize that the nature of these documents is totally different from that of our other

\footnotetext{
${ }^{5}$ D. Baharal, Victory of Propaganda. The Dynastic Aspect of the Imperial Propaganda of the Severi: the Literary and Archeological Evidence AD 193-235 (Oxford 1996), 34-42.

${ }^{6}$ Herodian 7.1.1. NB: Herodian already considered Septimius Severus to be a soldier emperor: cf. G. Alföldy, 'Zeitgeschichte und Krisenempfindung bei Herodian', Die Krise des römischen Reiches (HABES 5), (Stuttgart 1989), 273-294.

${ }^{7} \mathrm{X}$. Loriot, 'Les premières années de la grande crise du IIIe siècle: De l'avènement de Maximin le Thrace (235) à la mort de Gordien III (244)', in W. Haase and H. Temporini (Hrsgg.) Aufstieg und Niedergang der Römischen Welt II 2 (1975), 657-787; with an extensive (thematic) bibliography on pages 777-787.
} 
sources. Papyrus texts were written for private purposes, in the sense that they were not meant to last for generations, ${ }^{8}$ to reach a large public, or to influence public opinion, in the way that, for example, literary works, inscriptions, and coins did. Inherent to this private character of papyri is their variety of contents. As a result of the coincidental preservation of papyri, we have documents of various kinds, ranging from horoscopes to tax receipts, and from reports of proceedings to letters of fathers to their families. Among this variety of texts, there are also documents dealing with administrative matters of all kind, which we would call 'official', and would probably categorise differently from texts that were written by private individuals for private reasons, e.g. private correspondence. But however interesting a categorisation by topics may be, this is not a matter to be treated here. ${ }^{9}$ Still, we should not forget that none of the texts, whatever their 'category', were meant to survive. That they all provide us with very interesting information about Roman Egypt remains a fortunate coincidence.

In this paper, 13 texts are taken into account. Criteria by which they were chosen are firstly the secure dating to $\mathrm{AD} 238^{10}$ and secondly the presence of imperial titulature. Of these texts, 10 deal with public, and 3 with private matters. In almost all cases the imperial titulature is used to date the document or the 'action' described within the document; only in $\mathrm{nr} 4$ this may not be true. ${ }^{11}$ However, one may wonder what exactly the function of a dating formula was. Was it used simply to date a document, or is there more to it? Did it give a document its official character, for instance? And what about the titles that were used: were they chosen at random, or may we assume that they were used for some purpose, say propaganda? And do the texts from the year $\mathrm{AD} 238$ bring anything to light that may have a more general applicability? I am not claiming that I will offer definite answers to those questions; but it will, nonetheless, be interesting to compare the

\footnotetext{
${ }^{8}$ However, for private purposes, documents might be copied over and over again, so that as a result they sometimes did last for generations.

9 The texts examined here can all be considered 'official'. On categorisation or typology of papyrus documents, see R.S. Bagnall, Reading Papyri, Writing Ancient History (London - New York 1995), $22-24$.

${ }^{10}$ Texts that are dated in the reign of Maximinus (and Maximus) and of Gordian III alone, but without certainty for the year, are not taken into account. The relevant texts are gathered in the appendix.

${ }^{11}$ E.g. in nos. 7 and 8 the year of the harvest is dated by means of the imperial titulature. $\mathrm{Nr} 4$ is difficult to interpret: see the introduction and comment by the editor, P. Oxy. 51, 3607. That the titulature in $\mathrm{nr} 6$ is used to date the document, is suggested by the editor (P.Flor I 98, note to lines 5-6). $\mathrm{Nr} 12$ is too damaged to make any certain statements about the titulature.
} 
different titulatures used in the documents. In this way, it is at least possible to see in what way the different emperors were presented.

The construction and development of imperial titulature is an interesting phenomenon. As Hammond has described in his article on imperial elements in the formula of Roman emperors, official imperial titulature consists of republican and imperial elements. ${ }^{12}$ His investigation, however, focused on inscriptions and coins. If we now turn to imperial titulature that is used in papyrus texts, several features become clear. To begin with, most papyrus texts were written in Greek. As for the imperial titulature, this means that the Latin titles are translated in Greek, which is not very surprising. However, when imperial titles are used, we see that in most cases the republican elements are left out. Only in documents in which the emperor himself addresses the receiver directly, like edicts, the more elaborate titulature is used. The reason why the republican elements were left out in most texts, can only be guessed at. Was this for the sake of brevity? It may have had to do with the fact that use of the emperor's name to simply date documents did not need repetition of his exact powers. They did not matter, or in any case would not be of additional value. Use of the emperor's name and - when one chose to do so - honorific additions conferred enough reverence. In any case, the republican elements were not the most indispensable elements for referring to the emperor.

The imperial part of the titulature can be divided in five elements: ${ }^{13}$

1. Imperator Caesar Augustus; 2. praenomen and/or nomen gentile and/or cognomen ${ }^{14}$ 3. honorific epithets, e.g., pius, felix; 4. victory titles, e.g. parthicus; 5 . emphasis on the hereditary nature of the imperial position by means of listing predecessors, especially in the $2^{\text {nd }}$ and early $3^{\text {rd }}$ century. ${ }^{15}$

Although in this basic structure of the imperial titulature we can observe continuity from the Augustan era up to the third century, there were changes as well: by the time the Severan dynasty had come to power, the imperial titulature had grown in length. More important than the increasing length, however, was the shift from personally applicable titles to generalized standard titulature. A good example of this phenomenon is visible in the development of the meaningful name Imperator Caesar

\footnotetext{
${ }^{12} \mathrm{M}$. Hammond, 'Imperial Elements in the Formula of the Roman Emperors during the first two and a half Centuries of the Empire', Memoirs of the American Academy in Rome 25 (1957), 20-21.

${ }^{13}$ Hammond 1957, op.cit. (n. 12), 20-21 discerned four elements, considering victory titles as honorific epithets; $21-58$ gives a further discussion of these elements.

${ }^{14}$ One or more of these names are inserted between Imperator Caesar and Augustus.

${ }^{15}$ Hammond 1957, op.cit. (n. 12), 55-58; this practice died out after Severus Alexander.
} 
Augustus, that Octavian had created for himself. ${ }^{16}$ It was passed on to his successors and, as the empire and the imperial constitution developed, became a purely authoritative designation. ${ }^{17}$ The same applies to the honorific epithets: originally meant to specify (qualities of) a particular emperor, e.g. pius for Antoninus, they became mere descriptions of imperial merits, independent from the emperor. ${ }^{18}$

Although Hammond confined his research to the first two and half centuries of the empire, I think it is legitimate to apply Hammond's division of the imperial titulature to the titles in the Greek texts from $\mathrm{AD} 238$. The imperial titulature had by then achieved the standard form, which can, at least in papyri, still be recognized in the titulature of the following generations of emperors. With regard to our selected papyrus texts, we can make the following observations: ${ }^{19}$

- The first element occurs in almost all titles. The Latin imperial designation 'Imperator Caesar Augustus' is rendered in Greek as Av่

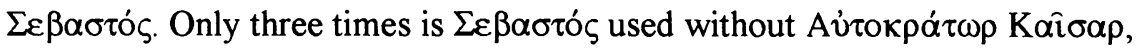

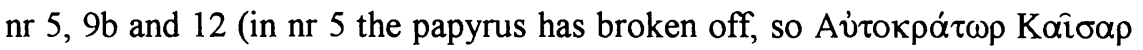
might have been there, and 12 is heavily damaged). In $3 a, 3 b, 4$, and $13 a$

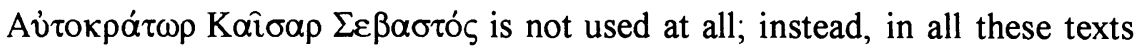
but for the heavily damaged $\mathrm{nr} 4$, after the emperor's names

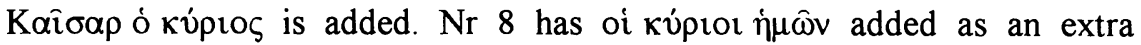
element before the imperial title, nomina and epithets.

- The second element occurs in all attested titles in elaborate form (i.e., the complete series of names). Only in nos. 6 and 10, one of the nomina of

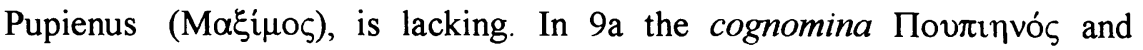
$\mathrm{B} \alpha \lambda \beta i v o \varsigma$ are erased; this is probably a consequence of damnatio memoriae. $^{20}$

- Honorific titles, which form the third element are listed in almost all cases.

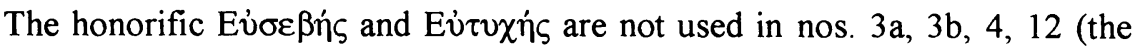
latter two are too damaged to be sure whether it was there) and 13a.

- Victory titles are only attested for Maximinus and Maximus. The other emperors were in power for too brief a period to have received any victory titles.

\footnotetext{
${ }^{16}$ R. Syme, 'Imperator Caesar: A Study in Nomenclature', Roman Papers I 29 (Oxford 1979), 361377 , argues on page 374 that Augustus 'exalts himself above all rivals or forerunners in the choice of names as of titles.'

${ }^{17}$ Hammond 1957, op.cit. (n. 12), 21-41, 58, 60 .

${ }^{18}$ Hammond 1957, op.cit. (n. 12),41-54.

${ }^{19}$ For the imperial titulature in the texts from $\mathrm{AD} 238$, see appendix

${ }^{20}$ D. Kienast, Römische Kaisertabelle ${ }^{2}$ (Darmstadt 1996), 191-194.
} 
- The fifth element, listing of the predecessors, does not occur in our sample, and actually this element is missing in imperial titulature in papyri in general. ${ }^{21}$ On the other hand, in nr 1 Maximinus' son is described as

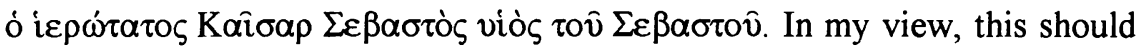
not be taken as listing of a predecessor, but rather as a reference to the dynastic stability Maximinus pretends to secure. This father-son relationship occurs in more papyrus texts containing titulature of Maximinus and Maximus. ${ }^{22}$ The same phenomenon can be observed in $\mathrm{nr} 4$, lines 9-10 (here

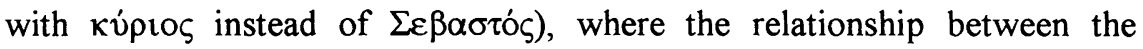
Gordians is made clear.

From this comparative overview, we can deduce that the overallstructure of the imperial titulature is identical for the different emperors. At the same time, the occurrence of slight differences suggests flexibility. What can we learn from those observations considering representation or perception of the emperors of the year $\mathrm{AD} 238$ ?

As stated above, papyri containing imperial titulature can all be considered official documents. May we, therefore, assume that occurrence of imperial titulature is expected to follow official prescripts? Although the titulatures we have seen show close similarities, it is apparent that the scribe had freedom to choose between different descriptions. The number of texts considered here is very small; the variation in titulature no doubt was much bigger than the one represented here. ${ }^{23}$ On the other hand, it may be significant that even with so few texts preserved, there are so many similarities between them. So, to come back to the 'officiality' of titulature: how was a new emperor communicated to the inhabitants of the empire? And was an official titulature communicated along with the emperor?

When a new emperor was proclaimed, his proclamation and titulature had to be confirmed and offered to him by the senate. ${ }^{24}$ The position of the senate, and therefore its role in 'creating' a new emperor, had become weaker in the course of time. A good example of this is Maximinus Thrax, who owed his imperial position exclusively to his soldiers. This soldier-

\footnotetext{
${ }^{21} \mathrm{P}$. Bureth, Les Titulatures impériales dans les papyrus, les ostraca et les inscriptions d'Égypte (30 a.C.- 284 p.C.) (Bruxelles 1964), passim.

${ }^{22}$ Bureth 1964, op.cit. (n. 21), 111-12, nr 1; 4; 6; 9;10;11 (nr 11 on p. 112 has maîc instead of vióc) NB: the numbers are not printed in Bureth's compilation.

${ }^{23}$ For numerous variations in imperial titulature in general, one just has to browse through the works of Bureth, 1964, op.cit. (n. 21) or M. Peachin, Roman Imperial Titulature and Chronology, A.D. 235284, (Amsterdam 1990).

${ }^{24}$ Peachin 1990, op.cit. (n. 23), 3-7; R. Talbert, The Senate of Imperial Rome (Princeton - New Jersey 1984), 354-356.
} 
based regime was a thorn in the flesh of the senate. So, when in AD 238 in Africa Proconsularis a rebellion broke out, ${ }^{25}$ and the two Gordians were proclaimed emperors, the senate was quick to undertake action. Letters were sent to the governors of the provinces to inform them of the political situation and of the senatorial decision to support the new rulers. However, since the new emperors were killed within a few weeks, the senate had little choice but to push through its own policy, i.e., to get rid of Maximinus, and appoint two senators as the new emperors. The Roman mob was outraged, and the senate could only 'agree' with having a child, the grandson of the first Gordian, acclaimed designated emperor. After a reign of a few weeks, the senatorial emperors were killed, and the designated Caesar was acclaimed emperor Gordian (III). Within half a year, three imperial acclamations of five emperors had taken place. So, three times, letters of notification of this must have been sent to the provinces. The contents of such letters can only be guessed at. They may have contained the official titulature of the new emperor, so that all officials who were active in the administration of the empire at once knew how to refer to their new ruler. Or perhaps only the fact of the proclamation of a new emperor was communicated, without prescribed standard formulas. The provincial administrators, familiar with using imperial titulature, knew exactly how to make a new imperial title out of the personal names of the new emperor. It is more probable that the senate communicated the new emperor and his new titles at the same time. The close parallels in the titulature that we have seen above can be taken as a support for this hypothesis. It has been assumed that such a communication, in which dating formulas were prescribed, in Egypt took place every year after the Diocletianic reforms; the prefect of Egypt in Alexandria acted as the intermediary between the central and provincial administration. ${ }^{26}$ This annual communication of the state of imperial affairs may well have been a continuation of an earlier practice. Although the titles were only used for dating purposes, they still reflect imperial merits, especially in the use of victory titles and epithets. Can this kind of use of imperial titulature be considered propaganda? The uniformity in titulature in papyrus texts is not uniform enough to prove deliberately chosen formulas, whereas the diversity is not diverse enough to disprove it. Regarding

\footnotetext{
${ }^{25}$ For a description of the course of the revolt and events related to it, see Loriot 1975, op.cit. (n.7), esp. 688-724.

${ }^{26}$ R.S. Bagnall, A. Cameron, S.R. Schwartz, K.A. Worp, Conculs of the Later Roman Empire (Atlanta, Georgia 1987), 67-8.
} 
documentary sources that make use of elements such as imperial acclamations and tribunician powers, which are helpful to date the document, I think there is truth in Kienast's statement: 'Man muß ferner betonen, daß alle die eben genannten, für die Datierung wichtigen Elemente primär einen politischen Charakter tragen und ihre chronologische Bedeutung meist erst sekundärer Natur ist. ${ }^{27}$ Certainly, use of the imperial titles does suggest an awareness of, and familiarity with, the constitutional power; apparently one had some freedom of choice, though the easiest thing to do was to stick to the example set by the highest authorities. However, the question remains whether use of imperial titulature in papyrus texts is purposeful propaganda. Rather, if one defines propaganda as a process in which several factors are involved, as Baharal does, it appears again that use of imperial titles to date documents should not be considered as pure propaganda. Baharal argues that 'In summary, there are six elements involved in the process of propaganda: the initiator, audience, medium, symbols or words, message and purpose'. ${ }^{28}$ If this model is applied to papyrus texts, a general statement about the use of titulature as propaganda would be something like: “'Advertising' the emperor propagated by the highest authorities to reach the subjects in order to get support for the (new) emperor was conveyed by means of written words." In this, the advertising of the emperor can be regarded as the message that was meant to be made public; the initiator responsible for sending out this message would be the highest authorities; its audience, of course, the subjects; purpose of transmitting the message would be to make the emperor acceptable, and, therefore, have him accepted. This would all be achieved by means of using imperial titulature, written down on papyrus. The only respect in which imperial titulature in papyrus texts does not fit into this scheme is that it is used not as a message per se, but rather as an addition, maybe even enrichment of a text, with the very practical purpose of dating the document. Therefore, I would plea to consider the use of imperial titulature in most papyrus texts not as propaganda in itself, but as as a reflection of this 'propagandistic' policy.

The question how the message that had been sent out was perceived is difficult to answer. Since it is not possible to look into people's minds, we

\footnotetext{
${ }^{27}$ Kienast 1996, op.cit. (n. 20), 21. Kienast mentions the 'eben genannten Elemente' on p. 20-21, for example consulates, imperial acclamations and victory titles. For a monograph on the latter category, victory titles, see P. Kneißl, Die Siegestitulatur der römischen Kaiser, Hypomnemata 23, (Göttingen 1969).

${ }^{28}$ Baharal 1996, op.cit. (n. 5), 2.
} 
can only hypothesise about this. But the fact that in most of the cases there is great similarity in the titulature that was used suggests that on the one hand the authors of the documents were not too critical in their choice of titles. On the other, they did not do their best to be inventive either. Writing down imperial titulature was a mechanical, but necessary, act. The suspicion rises that one perceived the emperor as an authority rather than as an individual, and, consequentially, that in using titulature it mattered more to express that authority than to link it to a man.

The fact that we have papyrological evidence attesting all the emperors proclaimed by the senate in $\mathrm{AD} 238$ proves that Egypt was loyal to Rome: it means that the people who were responsible for the administration, and therefore government, of Egypt were loyal to their superiors in Rome. The use of the imperial titles, even if only to date a document, was a way to express this loyalty.

When notifying the provincial administration after the proclamation of an emperor, the senate communicated the imperial titulature to present the new emperor. Though there are only very few documents attesting the

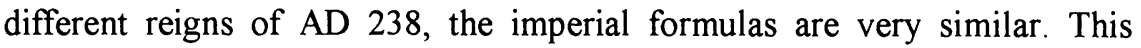
points to the existence of an official standard titulature that could be used for any emperor. We have seen that imperial titulature in general consisted of certain elements that are mutatis mutandis applicable to all emperors. The papyrus texts from $\mathrm{AD} 238$ illustrate this very well: considering the shortness of some of the reigns in AD 238, we can only admire the speed of the Roman administration in adapting to new rulers. The standard elements, in which only the personal nomina of the ruling emperor should be filled in at the adequate place, were very convenient. Besides that, the emperors of $\mathrm{AD} 238$ were almost proclaimed ad hoc, which caused the practical problem that there was no time to think elaborately about individualised titulatures. The standard was simply applicable to anyone.

In terms of representation, we can say that standardisation of formulas and the absence of individualisation, except by using the emperor's personal name, may not have had a propagandistic effect to promote the individual emperors, but maybe the appearance of continuity of imperial authority was created by using generalized structures. In this sense it did have a propagandistic effect for 'the emperorship'. In any case, in the third century it was the authority of the emperor that mattered, not his personal qualities. 
Following this, in terms of perception we may conclude that in Egypt in this period the emperor was not perceived as an individual with personal qualities, but rather as the person who was merely filling in a vacant place. Local administrators followed the instructions they got from higher hand. Thanks to standard titles they were able to change quickly from one emperor to another in writing their documents. Although we can never be sure of what people were actually thinking, it is likely that the presentation of the emperor determined the way in which he was perceived. This applies to presentation and perception of imperial power by means of titulature in Greek texts of $\mathrm{AD} 238$ as well: perception of the emperor depended on how he was presented. His abstract presence was rendered by the use of titles. For the authors of the documents under consideration and the people who would deal with them, that sufficed.

Nijmegen, October 2002 


\section{Appendix: Imperial titles in Greek texts from AD $238^{29}$}

\section{SPP XX 37, 12-18 (29-1-238)}

Public (administrative): registration of cattle, addressed to the basilikos grammateus. Titulature used to date the document.

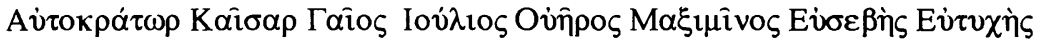

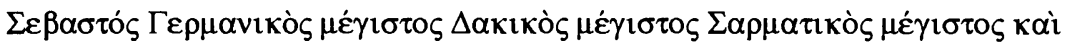

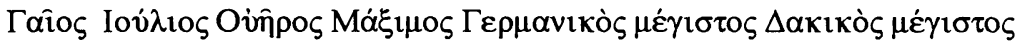

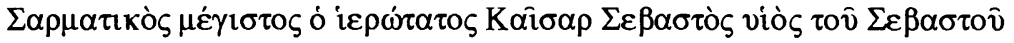

\section{SPP XX $47=$ CPR 6, 1-2 (3-2-238)}

Private: contract of a sale of land. Titulature used to date the document.

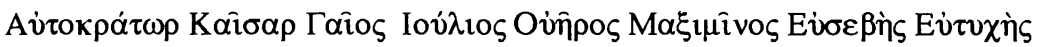

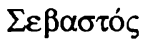

\section{3. a. P.Oxy. XLIII 3107, 2-5 (7-4-238)}

Public (administrative): receipt for dyke- and other taxes. Titulature used to date the document.

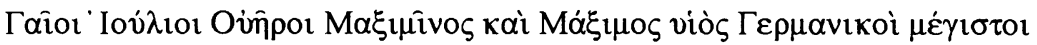

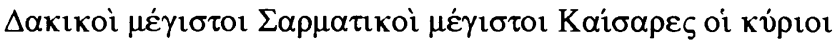

\section{3. b. P.Oxy. XLIII 3107, 12-15 (13-6-238)}

Public (administrative): receipt for dyke- and other taxes. Titulature used to date the document.

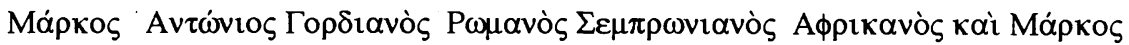

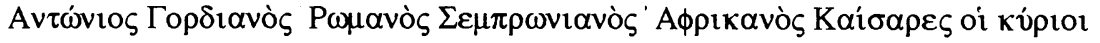

\section{P.Oxy. LI 3607 (before 13-6-238)}

Accession edict; titles too damaged to be sure, and so is the purpose of the titulature used.

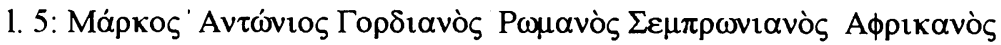

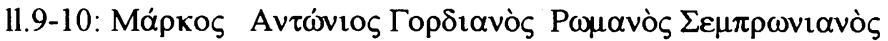

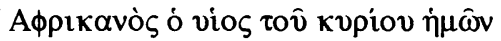

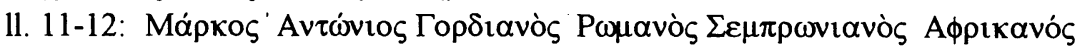

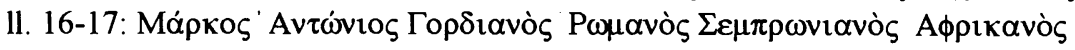

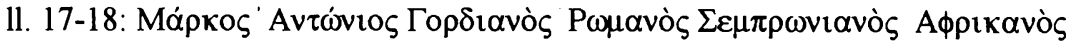

\footnotetext{
${ }^{29} \mathrm{NB}$ : the titulature is rendered in the nominative case here (whereas in the documents they are in genetive case). Furthermore, I took over the titulatures as they were restored by the various editors: in most texts the titulature survived in such way that restoration is more or less secure; only nos. 4, 6, 11 and 12 are very damaged and should be considered with extra caution. Also the spelling has been

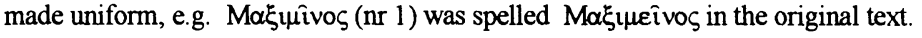


5. SB XVIII 13153, 1-4 (20-6-238)

Private: end of a renting contract. Titulature used to date the document/year of the lease (?).

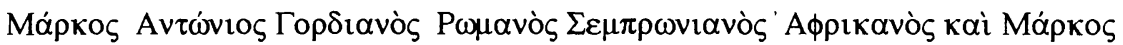

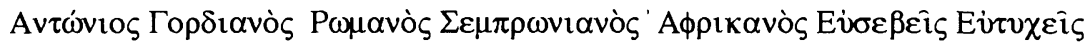
$\Sigma \varepsilon \beta \alpha \sigma \tau o i$

6. P.Flor. I 98, 5-6 (238)

Public (administrative): order of the basilikos grammateus

Use of titulature not clear. Restored by editor (note to line 5-6)

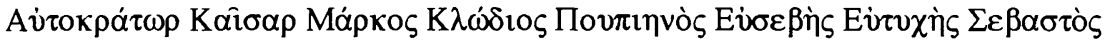

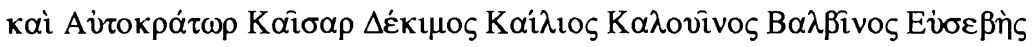

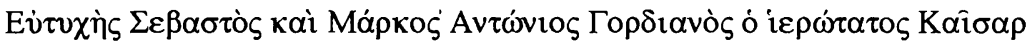

7. O.Leid. 259, 2-8 (21-7-238)

Public (administrative): granary receipt. Titulature used to date the year of the harvest.

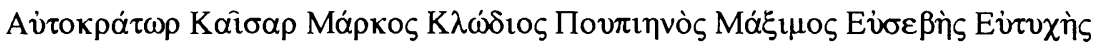

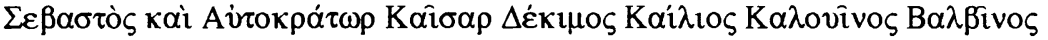

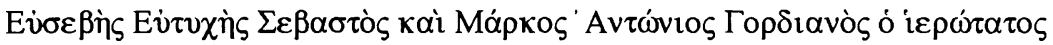

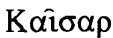

8. O.Bodl. II 1621, 1-4 (21-7 and 11-8 238)

Public (administrative): granary receipt ( $\mu \epsilon^{\epsilon} T \rho \eta \mu \alpha$ Oncavpoû). Titulature used to date the year of the harvest.

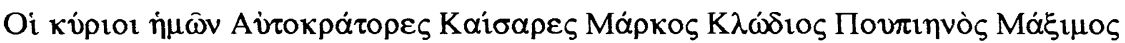

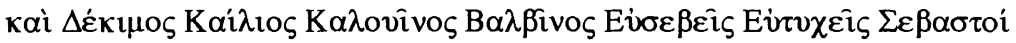

9.a. P. Oxy. XII 1433, col. i, 16-26 (29-8 to 27-9 238)

Public (administrative): reports of tax-collectors to a strategos. Titulature with part of the names deleted. Titulature used to date the year for which the taxes had been paid.

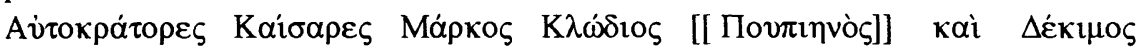

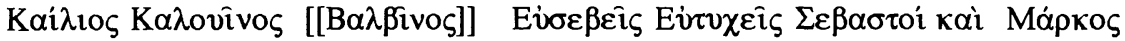

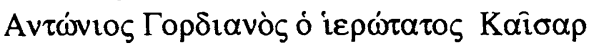

9.b. P. Oxy. XII 1433, col. ii, $45-49$ (28-9 to 27-10 238)

Public (administrative): reports of tax-collectors to a strategos. Titulature used to date the year for which the taxes had been paid.

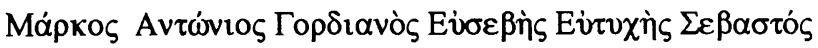


10. SPP XX 51, 21-25 (8-9-238)

Private: contract of loan of grain. Titulature used to date the document.

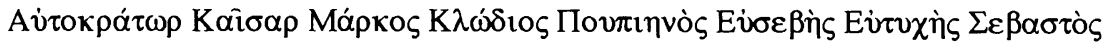

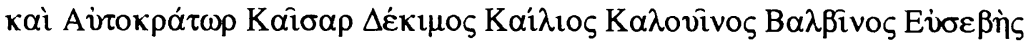

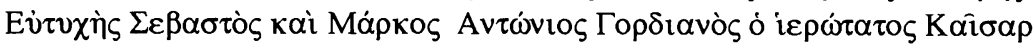

11. P.Heid. Inv. G 175R, 1-2 Summer 238 (ined.)

Public (administrative): end of a petition. Titulature used to date the document and mostly restored.

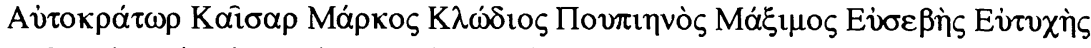

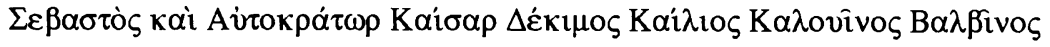

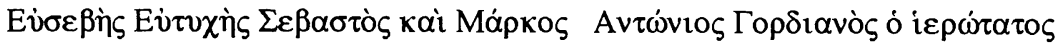

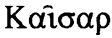

12. P.Heid. Inv. G 546 (238) (ined.)

Public (administrative). Petition? (Too damaged to determine)

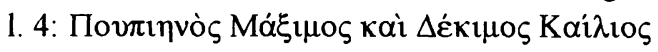

1. 5: $\Sigma \varepsilon \beta \alpha \sigma \tau o i ́$

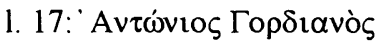

13.a. P. Ryl. II 100, 4-5 (12 October 238)

Public (administrative): application for a lease of land to pasture sheep

Titulature to denote the year for which the lease is set

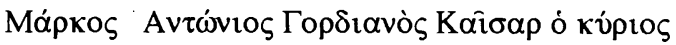

13.b281 P. Ryl. II 100, 15-17 (12 October 238)

Titulature to date the whole document

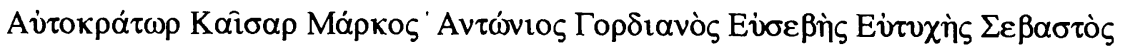

